\title{
Examining the STEM Awareness and Entrepreneurship Levels of Pre-Service Science Teachers
}

\author{
Selcen Süheyla Ergün \\ Correspondence: Selcen Süheyla Ergün, Faculty of Education, Afyon Kocatepe University, Turkey.
}

Received: January 9, 2019

doi:10.11114/jets.v7i3.3960

\author{
Accepted: January 31, $2019 \quad$ Online Published: February 15, 2019 \\ URL: https://doi.org/10.11114/jets.v7i3.3960
}

\begin{abstract}
The scientific and technological developments in today's world require countries to raise entrepreneurial, productive, critical, problem-solving, and entrepreneurial individuals. Therefore, STEM (Science, Technology, Engineering, and Mathematics) education has gained importance today. STEM education is defined as an approach that takes an interdisciplinary relationship and takes a holistic approach to science, technology, engineering, and mathematics. STEM education includes the activities that will increase the students' interest and orientations towards science, technology, engineering, and mathematics fields using the skills that should be possessed today. The aim of this study was to examine the STEM awareness and entrepreneurship levels of pre-service science teachers. The sample of the study consisted of 93 female and 20 male students studying in the Science Education Department at Afyon Kocatepe University. As a quantitative research type, survey method was used in this study. "STEM Awareness Scale" (SAS) developed by Buyruk and Korkmaz (2016) and "Entrepreneurship Scale for Teacher Candidates" developed by Deveci and Cepni (2015) were used as data collection tools. As a result of analyses, it was seen that science teachers' attitudes towards STEM education were positive. Females' STEM awareness was significantly higher than males' in both positive and negative sub-factors. STEM awareness of the first grade students was significantly lower than the other classes in the positive sub-factor, and significant differences were found between the first grade and second grade, and the second grade and the fourth grade in the negative sub-factor. There were no significant differences of entrepreneurship levels in terms of gender. Also, the entrepreneurship characteristics of the second grade were significantly higher than the other grade levels.
\end{abstract}

Keywords: STEM awareness, pre-service science teachers, entrepreneurship

\section{Introduction}

In the economic, social, and political areas of the globalizing world, various changes and developments occur. To be able to use science and technology effectively, the changes of countries are also very fast. These changes in the $21^{\text {st }}$ century naturally differs the expected competencies, and the need for students who are thinking, producing, questioning, and contributing to economic and social developments is increasing day by day (Ministry of National Education, 2016).

STEM training is one of the most popular educational models in the world in recent years and plays an important role in the development of $21^{\text {st }}$ century skills. STEM training, which provides the integration of the disciplines of science, technology, engineering, and mathematics, is an innovative approach and supports the upbringing. STEM is a concept formed by the combination of science, technology, engineering, and mathematics disciplines (Bybee, 2013; Riechert \& Post, 2010; Haciomeroglu \& Bulut, 2016). It was first used by Judith A. Ramaley, the director of The National Science Foundation, in 2001, as STEM which is derived from education term or concept (Teaching Institute for Excellence in STEM, 2010). Today, rapid development of science and technology requires individuals to have the ability to overcome the problems encountered in real life, to transfer the new information they have acquired in real life environments, and to have the skills to use their knowledge in the right place and at the right place (Gonzalez \& Kuenzi, 2012; Yildirim \& Selvi, 2015; Baran, Canbazoglu-Bilici \& Mesutoglu, 2015). Common purpose of many disciplines associated within them in accordance with the information learned by the individual in the daily life of the experiential information provides holistic and meaningful learning. STEM education provides the students with the disciplines of science, technology, engineering, and mathematics and provides effective learning in students with quality learning environment (Corlu, Capraro \& Capraro, 2014; Roberts, 2012; Akaygun \& Aslan-Tutak, 2016).

It is possible to increase the interest and skills in science, technology, engineering, and mathematics with the activities 
in STEM education (Baran, Canbazoglu Bilici \& Mesutoglu, 2015). One aim of STEM training is to transform theoretical knowledge into practice, production, and innovative discovery. STEM education increases students' critical thinking and problem solving skills. Therefore, many countries have included STEM in their curricula (Corlu and Aydin, 2016). STEM education is an interdisciplinary approach that covers a process from primary school to undergraduate level. In this sense, it gives individuals the ability of problem solving and interdisciplinary relationship with a holistic approach (Sahin, Ayar \& Adiguzel, 2014). According to Corlu (2012), in order to reach the STEM education goals, it is important that "STEM Education teachers" need to be trained adequately. If there are some shortcomings about the teachers, STEM training may be incomprehensible and complicated and could not reach the goals of STEM education.

Using the term STEM for the first time in the 1990s, National Science Foundation (NSF) covered the content of STEM training and emphasized the importance of STEM education. Many international studies involving STEM have been conducted (Buxton, 2001; Cleaves, 2005; Nadelson, Seifert, Moll \& Coat, 2012; Bracey, Brooks, Marlette and Locke, 2013; Pinnell et al., 2013). Also, the number of studies related to STEM in Turkey has increased in recent years (Sahin, Ayar \& Adiguzel, 2014; Baran, Bilici \& Mesutoglu, 2015; Gencer, 2015; Yildirim \& Altun, 2015; Cevik, Danistay \& Yagci, 2017).

Bozkurt Altan, Yamak, and Bulus Kirikkaya (2016) examined pre-service teachers' views on STEM. They stated that design-based science education is motivating and has a positive effect on inquiry-based teaching. Yamak, Bulut, and Dundar (2014) investigated the effects of STEM activities on the attitude towards science process skills and science. They stated that STEM activities have a positive improvement effect on students' scientific process skills and science. Karakaya and Avgin (2016) conducted a study to determine the effect of demographic characteristics on the attitudes of secondary school students towards STEM. They found that parents' education level has an effect on the attitude of the middle school students towards STEM. But, they stated that gender and grade level have no effect on the attitude towards STEM.

Most of these studies on STEM are for scale development or scale adaptation. These studies generally aim to determine the awareness of teacher and teacher candidates on STEM. "Integration of Mathematics, Science, and Technology Education Scale" developed by Derin, Yasin, Aydin, and Delice (2014) was used to determine the attitudes of pre-service teachers in mathematics, physics, biology, chemistry, and computer education. Another study was conducted by Karakaya, Unal, Cimen, and Yilmaz (2018) to examine the awareness of STEM approach of science teachers in terms of some variables. As a result of the study, while there were significant differences according to gender, professional experience, in-service training and education level, there was no significant difference according to grade level or type. Ozbilen (2018) examined the perspectives and awareness of teachers about STEM education. Research results showed that science teachers know the STEM model better than other teachers and that science and mathematics teachers see STEM model as indispensable.

Entrepreneur is a person who demonstrates and promotes a certain project to develop in accordance with entrepreneurship (Ozkan, Gundogdu, Emsen \& Aksu, 2003). Entrepreneurship is the process of putting together the financial, social, and psychological risks by combining the necessary time and effort together and introducing something that is different from the monetary and personal reward (Naktiyok, 2004). Entrepreneurship is influenced by education and training as it will be acquired through culture and experience. One of the most striking results of the GEM 2000 report is that entrepreneurship education is the most important element in the entrepreneurship process. Therefore, the development of the content and methods of the entrepreneurship education program is not an option but a basic requirement (Yildirim, 2008). Entrepreneurship training consists of all kinds of experiences about how students can combine talent and vision and transform them into different opportunities. Entrepreneurship has been one of the most discussed topics in our country as is the case in the world in recent years (Aydin \& Celik, 2013).

In developing teachers' competencies, the teacher needs to make self-assessment and change for continuous improvement, open to new knowledge and ideas, and develop itself and the institution. There is undoubtedly an important role in the training of individuals with entrepreneurship characteristics. For this reason, one of the skills intended to be taught to students in the curricula of countries is the ability of being an entrepreneur. Therefore, the concept of entrepreneurship is included in the curriculum of our country as the basic skills and intermediate discipline acquisition (Ministry of National Education, 2006). When the teaching profession is examined, some of the entrepreneurial skills in entrepreneurs are learning, monitoring and evaluation of development, environment and recognition of students, and public relations (Yilmaz \& Sunbul, 2009). In preparing students for life, it has become obligatory to educate them as entrepreneurs by taking into account that learning is not limited to schools and continues throughout life. In order to provide individuals with entrepreneurial skills, learning environments must be created and teachers who have the skills to gain these skills should have entrepreneurial skills. In this case, entrepreneurship also comes to the fore in STEM education. Drawing attention to the content of STEM education started by the National Science Foundation in the 1990s and many studies have been carried out in the international literature. When these 
studies were examined, it can be stated that most of the studies were about developing scales or adapting foreign scales about the awareness of teacher/teacher candidates about STEM. However, STEM education is an approach that requires the use of a large amount of interdisciplinary information. One of these approaches is entrepreneurship. In this context, it can be assumed that a relationship can be established between two concepts. Hence, in this research, the awareness of pre-service teachers about STEM and entrepreneurship levels was discussed together.

\section{Method}

\subsection{Research Subjects}

The aim of the study was to examine the STEM awareness and entrepreneurship levels of pre-service science teachers. In this study, the level of pre-service science teachers' awareness about STEM, the level of pre-service science teachers' entrepreneurship, the relationship between the levels of pre-service science teachers' awareness about STEM by gender, grade level, and entrepreneurship level, and the relationship between the levels of pre-service science teachers' entrepreneurship by gender and grade level were researched.

\subsection{Research Methods}

This quantitative study was designed as a survey. According to Karasar (2014), researchers should use survey study design if they intend to describe a case as it exists, whether it is an event, individual, or object.

\subsection{Research Instruments}

In this study, the "STEM Awareness Scale" (SAS) developed by Buyruk and Korkmaz (2016) and the "Entrepreneurship Scale for Teacher Candidates" developed by Deveci and Cepni (2015) were used to collect the data.

The 17 items constituting the scale is collected under two factors. For each of the items in the scale, options presented as Strongly Disagree (1), Disagree (2), Undecided (3), Agree (4), Strongly Agree (5). On the other hand, the Cronbach alpha reliability coefficient of the scale is 0.92 . In this study, Cronbach alpha reliability coefficient of the scale was 0.88 .

Deveci and Cepni (2015) developed the "Entrepreneurship Scale for Teacher Candidates". The scale consists of 38 items and five sub-dimensions. These sub-dimensions include risk-taking, innovation, self-confidence, opportunities, and emotional intelligence.

\subsection{Data Collection}

The data were collected from 93 female and 20 male students from the Department of Science Education at Afyon Kocatepe University in 2017-2018 academic year. IBM SPSS 18 software was used to analyze the data. To analyze the normality of the data distribution, the Kolmogorov-Smirnov test was performed and it showed $(\mathrm{p}<0.05)$ that the data about STEM awareness did not have a normal distribution. So, the Mann-Whitney U test was used to make a pairwise comparison, and the Kruskal-Wallis test was used to make multiple comparisons. Because the data showed normal distribution about entrepreneurship level, parametric and non- parametric tests were used in the analysis of the research.

\section{Results}

Table 1 shows the descriptive analysis of the pre-service science teachers' scores on the STEM Awareness Scale.

Table 1. Descriptive analysis of the STEM Awareness Scale scores

\begin{tabular}{lccccccccc}
\hline \multirow{2}{*}{ Department } & \multicolumn{3}{c}{ Positive perspective } & \multicolumn{3}{c}{ Negative perspective } & \multicolumn{3}{c}{ Overall Scale } \\
\cline { 2 - 10 } & $\mathrm{N}$ & Mean & sd & $\mathrm{N}$ & Mean & sd & $\mathrm{N}$ & Mean & $\mathrm{sd}$ \\
\hline Science Education & 113 & 3.78 & 1.07 & 113 & 3.53 & 1.21 & 113 & 3.70 & .947 \\
\hline
\end{tabular}

The mean scores on the positive perspective sub-dimension $(\bar{X}=3.78)$, negative perspective sub-dimension $(\overline{\bar{X}}=3.53)$, and overall scale are shown in Table 1. It can be stated that pre-service science teachers have positive perceptions about the STEM education ( $\bar{\lambda}=3.70)$.

The variance of the pre-service science teachers' mean scores by gender is shown in Table 2 . 
Table 2. Mann-Whitney U test results for the comparison of the pre-service science teachers' mean scores by gender

\begin{tabular}{|c|c|c|c|c|c|c|}
\hline Scale & Group & $\mathrm{N}$ & Mean Rank & Sum of Ranks & $\mathrm{U}$ & $\mathrm{p}$ \\
\hline \multirow[t]{2}{*}{ Positive } & Female & 93 & 59.97 & 5577.00 & 654.000 & $.037 *$ \\
\hline & Male & 20 & 43.20 & 864.00 & & \\
\hline \multirow[t]{2}{*}{ Negative } & Female & 93 & 59.85 & 5566.00 & 665.000 & $.045^{*}$ \\
\hline & Male & 20 & 43.75 & 875.00 & & \\
\hline \multirow[t]{2}{*}{ Total } & Female & 93 & 60.45 & 5622.00 & 609.000 & $.016^{*}$ \\
\hline & Male & 20 & 40.95 & 819.00 & & \\
\hline
\end{tabular}

$* \mathrm{p}<0.05$

Table 2 shows that female pre-service science teachers have significantly more positive perceptions of STEM in the positive perspective, negative perspective sub-dimension, and the overall scale.

Table 3 shows the mean scores of the pre-service science teachers by grade level.

Table 3. Kruskal Wallis test results for the comparison of the pre-service science teachers' mean scores by grade level

\begin{tabular}{|c|c|c|c|c|c|c|c|}
\hline Scale & Groups & $\mathrm{N}$ & Mean Score & sd & $\chi^{2}$ & $\mathrm{p}$ & Significant Difference \\
\hline \multirow[t]{4}{*}{ Positive } & $1^{\text {st }}$ year & 27 & 39.65 & \multirow[t]{4}{*}{3} & \multirow[t]{4}{*}{11.543} & \multirow[t]{4}{*}{$.009 *$} & $1-2$ \\
\hline & $2^{\text {nd }}$ year & 32 & 68.13 & & & & $1-3$ \\
\hline & $3^{\text {rd }}$ year & 26 & 59.69 & & & & $1-4$ \\
\hline & $4^{\text {th }}$ year & 28 & 58.52 & & & & \\
\hline \multirow[t]{4}{*}{ Negative } & $1^{\text {st }}$ year & 27 & 46.07 & \multirow[t]{4}{*}{3} & \multirow[t]{4}{*}{14.276} & \multirow[t]{4}{*}{$.003^{*}$} & $1-2$ \\
\hline & $2^{\text {nd }}$ year & 32 & 73.19 & & & & $2-4$ \\
\hline & $3^{\text {rd }}$ year & 26 & 60.19 & & & & \\
\hline & $4^{\text {th }}$ year & 28 & 46.07 & & & & \\
\hline \multirow[t]{4}{*}{ Total } & $1^{\text {st }}$ year & 27 & 39.67 & \multirow[t]{4}{*}{3} & \multirow[t]{4}{*}{15.994} & \multirow[t]{4}{*}{$.001 *$} & $1-2$ \\
\hline & $2^{\text {nd }}$ year & 32 & 73.19 & & & & $1-3$ \\
\hline & $3^{\text {rd }}$ year & 26 & 59.56 & & & & $2-4$ \\
\hline & $4^{\text {th }}$ year & 28 & 52.84 & & & & \\
\hline
\end{tabular}

$* \mathrm{p}<0.0 \overline{5}$

The sophomore, junior, and senior pre-service science teachers in the Science Education Department had significantly more positive perspectives on STEM in the positive perspective sub-dimension when compared to the freshmen (Table 3).The freshmen and senior pre-service science teachers have more negative perspectives on STEM than the sophomore pre-service science teachers in the negative perspective sub-dimension of the scale. On the overall scale, the sophomore and junior pre-service science teachers have more positive perspectives on STEM than the freshmen, and the senior pre-service science teachers have more negative perspectives on STEM than the sophomores.

Table 4. Descriptive statistical results of the scores obtained by the pre-service science teachers in the Science Education Department

\begin{tabular}{ccccccccccccc}
\hline Grade Level & \multicolumn{3}{c}{ 1. Grade } & \multicolumn{3}{c}{ 2. Grade } & & 3. Grade & & \multicolumn{2}{c}{ 4. Grade } \\
\hline & $\mathrm{N}$ & Mean & $\mathrm{sd}$ & $\mathrm{N}$ & Mean & $\mathrm{sd}$ & $\mathrm{N}$ & Mean & $\mathrm{sd}$ & $\mathrm{N}$ & Mean & sd \\
\hline Total & 27 & 3.60 & .75 & 32 & 3.93 & .51 & 26 & 3.81 & .65 & 28 & 3.56 & .52 \\
& & & & & & & & & & & & \\
\hline Risk taking & 27 & 3.57 & .78 & 32 & 3.83 & .60 & 26 & 3.78 & .74 & 28 & 3.53 & .68 \\
\hline See opportunities & 27 & 3.62 & .68 & 32 & 3.99 & .48 & 26 & 3.89 & .71 & 28 & 3.56 & .69 \\
\hline Confidence & 27 & 3.74 & .82 & 32 & 3.98 & .63 & 26 & 3.82 & .75 & 28 & 3.50 & .69 \\
\hline $\begin{array}{c}\text { Emotional } \\
\text { intelligence }\end{array}$ & 27 & 3.62 & .82 & 32 & 4.03 & .58 & 26 & 3.75 & .73 & 28 & 3.62 & .68 \\
\hline Innovativeness & 27 & 3.46 & .95 & 32 & 3.81 & .62 & 26 & 3.78 & .70 & 28 & 3.60 & .50 \\
\hline
\end{tabular}


Table 4 shows the average of the scores of the teacher candidates in the Science Education Department from the sum of the scale and from each sub-dimension are above average. In other words, pre-service science teachers perceive their entrepreneurship characteristics as close to the upper level.

The results of the independent t-test conducted in order to determine whether the level of entrepreneurship of the pre-service science teachers studying in the science education department differed according to gender are given in Table 5 .

Table 5. Entrepreneurship levels of pre-service science teachers in the Science Education Department according to gender

\begin{tabular}{|c|c|c|c|c|c|c|c|}
\hline & Gender & $\mathrm{N}$ & Mean & $\mathrm{sd}$ & $\mathrm{T}$ & $\mathrm{df}$ & $\mathrm{p}$ \\
\hline \multirow[t]{2}{*}{ Total } & Female & 91 & 3.748 & .63 & .320 & 111 & .749 \\
\hline & Male & 22 & 3.7 & .62 & & & \\
\hline \multirow[t]{2}{*}{ Risk taking } & Female & 91 & 3.685 & .70 & .023 & 111 & .982 \\
\hline & Male & 22 & 3.688 & .73 & & & \\
\hline \multirow{2}{*}{$\begin{array}{l}\text { See } \\
\text { opportunities }\end{array}$} & Female & 91 & 3.784 & .67 & .199 & 111 & .843 \\
\hline & Male & 22 & 3.752 & .65 & & & \\
\hline \multirow[t]{2}{*}{ Confidence } & Female & 91 & 3.771 & .73 & .048 & 111 & .962 \\
\hline & Male & 22 & 3.779 & .77 & & & \\
\hline \multirow{2}{*}{$\begin{array}{l}\text { Emotional } \\
\text { intelligence }\end{array}$} & Female & 91 & 3.8 & .75 & .596 & 111 & .552 \\
\hline & Male & 22 & 3.688 & .614 & & & \\
\hline \multirow[t]{2}{*}{ Innovativeness } & Female & 91 & 3.692 & .731 & .669 & 111 & .505 \\
\hline & Male & 22 & 3.578 & .671 & & & \\
\hline
\end{tabular}

Table 5 shows that the level of entrepreneurship of the pre-service science teachers do not show a significant difference according to gender.

The results of the One-Way ANOVA test conducted in order to determine whether the entrepreneurship characteristics of the pre-service science teachers studying in the Department of Science Education differed according to the grade level are given in Table 6.

Table 6. omparing the difference between the levels of entrepreneurship of pre-service science teachers in the Science Education Department by class level

\begin{tabular}{|c|c|c|c|c|c|c|}
\hline Scale / Sub-Dimensions & Source & Squares Sum & sd & Squares Mean & $\mathrm{F}$ & $\mathrm{p}$ \\
\hline \multirow{3}{*}{ Total } & Between the Groups & 2.719 & 3 & .906 & \multirow[t]{3}{*}{2.406} & \multirow[t]{3}{*}{.071} \\
\hline & Within groups & 41.063 & 109 & .377 & & \\
\hline & Total & 43.782 & 112 & & & \\
\hline \multirow{3}{*}{ Risk-taking } & Between the Groups & 1.998 & 3 & .666 & \multirow[t]{3}{*}{1.348} & \multirow[t]{3}{*}{.263} \\
\hline & Within groups & 53.846 & 109 & .494 & & \\
\hline & Total & 55.843 & 112 & & & \\
\hline \multirow{3}{*}{ See opportunities } & Between the Groups & 3.802 & 3 & 1.267 & \multirow[t]{3}{*}{3.059} & \multirow[t]{3}{*}{$.031^{*}$} \\
\hline & Within groups & 45.161 & 109 & .414 & & \\
\hline & Total & 48.963 & 112 & & & \\
\hline \multirow{3}{*}{ Confidence } & Between the Groups & 3.650 & 3 & 1.217 & \multirow[t]{3}{*}{2.309} & \multirow[t]{3}{*}{.080} \\
\hline & Within groups & 57.437 & 109 & .527 & & \\
\hline & Total & 61.087 & 112 & & & \\
\hline \multirow{3}{*}{ Emotional intelligence } & Between the Groups & 3.315 & 3 & 1.105 & \multirow[t]{3}{*}{2.199} & \multirow[t]{3}{*}{.092} \\
\hline & Within groups & 54.765 & 109 & .502 & & \\
\hline & Total & 58.080 & 112 & & & \\
\hline \multirow{3}{*}{ Innovativeness } & Between the Groups & 2.323 & 3 & .774 & \multirow[t]{3}{*}{1.522} & \multirow[t]{3}{*}{.213} \\
\hline & Within groups & 55.476 & 109 & .509 & & \\
\hline & Total & 57.799 & 112 & & & \\
\hline
\end{tabular}

Table 6 shows that the level of entrepreneurship of the pre-service science teachers studying in the Science Education Department does not differ in any sub-scale except for the whole scale and the opportunity to see opportunities [F (3.112) $=2.406 ; \mathrm{p}>$. 05]. According to the LSD test results which performed in order to see which level of difference was in the sub-dimension of seeing opportunities, it was found that in the second and fourth year, there was a significant difference between the pre-service science teachers in favor of second grade students. 
Table 7. Spearman's Rho Correlation Coefficient results showing the relationship between scores obtained from the STEM Awareness Scale and Entrepreneurship Scale

\begin{tabular}{lccc}
\hline & Positive perspective & Negative perspective & Overall Scale \\
\hline Entrepreneurship level & .438 & .295 & .486
\end{tabular}

As shown in the table, there is a low level of relationship between pre-service teachers' level of entrepreneurship and their positive and negative perspectives towards STEM. On the other hand, there is a moderately significant relationship between the pre-service teachers' levels of entrepreneurship and levels of STEM awareness. In other words, the low / high level of student teachers' awareness level and low / high level of entrepreneurship can be explained by a moderate correlation in the positive direction.

\section{Discussion}

As a result of the study, the average of the responses to the positive sub-dimension of the scale was 3.78. In other words, it was observed that the pre-service science teachers participated in this dimension measuring the positive point of view of STEM. The mean score of negative sub-dimension was 3.53. In general, it is seen that the negative perspectives of pre-service science teachers towards STEM are slightly above the middle level. It was determined that pre-service science teachers developed positive perspectives towards STEM. This result shows that STEM education has positive perspectives towards STEM, which has been confirmed by many studies (Akaygun \& Aslan-Tutak, 2016; Adams, Miller, Saul \& Pegg, 2014; Corlu, Capraro \&Capraro, 2014; Yenilmez \& Balbag, 2016; Yildirim \& Selvi, 2015;). This also showed that pre-service science teachers had positive awareness of STEM. Moreover, there are some studies stating that high awareness of STEM can lead to positive perceptions and perspectives (Guzey, Harwell \& Moore, 2014; Schmidt \& Kelter, 2017).

In this study, there was a statistically significant difference between the mean values of males and females in both positive and negative sub-factors. Female pre-service science teachers had significantly more positive perceptions of STEM. Furthermore, Yenilmez and Balbug (2016) stated that women's STEM awareness was higher than men in all departments in their studies. However, Cevik, Danistay, and Yagci (2017) found no significant difference in the teachers' awareness of STEM according to gender.

As a result of the grade level analysis conducted in pre-service science teachers, there was a statistically significant difference between the first grade and other classes in the positive sub-factor. And also, a significant difference was found between the first and second grades and the second and fourth grades in the negative sub-factors. However, the senior pre-service science teachers had less negative perceptions of STEM in the other sub-dimensions of the scale and the overall scale than the sophomores. The reasons for this can be investigated in further qualitative research.

The entrepreneurship findings of the research showed that the pre-service science teachers perceived the entrepreneurship characteristics at a high level. In similar studies conducted, it was determined that pre-service science teachers were at high entrepreneurship level (Yilmaz \& Sunbul, 2009; Pan \& Akay, 2015). Although the reasons for this result were not revealed in the current research, Irmis and Barutcu (2012) stated that variables such as family, education, place of birth, and personal values came to the fore in the emergence of entrepreneurship characteristics. However, the qualitative studies will be able to examine the factors affecting the formation of entrepreneurial characteristics.

When it was examined whether the entrepreneurship levels of the pre-service science teachers differed according to the gender variable, it was detected that there was no significant difference in entrepreneurial characteristics according to gender. When examined in general terms, it was seen that there was no significant difference in terms of gender variable as in the study conducted by Pan and Akay (2015). This situation can be interpreted as a result of pre-service science teachers come from similar socio-cultural environments and economic levels.

When the entrepreneurship levels of pre-service science teachers were examined by the level of the class, there was a significant difference between the pre-service science teachers in the Department of Science Education only in the sub-dimension of seeing opportunities. However, it is the development of entrepreneurial characteristics of individuals who are expected from modern education (Rae \& Carswell, 2001). In this context, courses can be given to develop the entrepreneurial characteristics of pre-service science teachers in the faculties of education.

Findings showed that here was a low level of relationship between pre-service teachers' level of entrepreneurship and their positive and negative perspectives towards STEM. On the other hand, there was a moderately significant relationship between the pre-service science teachers' levels of entrepreneurship and STEM awareness. In other words, the low / high level of student teachers' awareness level and low / high level of entrepreneurship can be explained by a moderate correlation in the positive direction. 


\section{Acknowledgements}

This study was supported by Afyon Kocatepe University BAP, Project number: 18.Kariyer.73.This article is an extended version of a paper presented in INTE (International Conference on New Horizons in Education) 2018.

\section{References}

Adams, A. E., Miller, B. G., Saul, M., \& Pegg, J. (2014). Supporting elementary pre-service teachers to teach STEM through place-based teaching and learning experiences. Electronic Journal of Science Education, 18(5).

Akaygun, S., \& Aslan-Tutak, F. (2016). STEM images revealing stem conceptions of pre-service chemistry and mathematics teachers. International Journal of Education in Mathematics, Science and Technology, 4(1), 56-71. https://doi.org/10.18404/ijemst.44833

Aydin, M., \& Celik, T. (2013). The prospective teacher' opinions relating reflective thinking skills. Pamukkale University Journal of Education Faculty, 34(2).

Baran, E., Canbazoglu-Bilici, S., \& Mesutoglu, C. (2015). Science, technology, engineering, and mathematics (STEM) public service announcement (PSA) development activity. Journal of Inquiry Based Activities, 5(2), 60-69.

Bozkurt, A. E., Yamak, H., \& Bulus, K. E. (2016). A proposal of the STEM education for teacher training: design based science education. Trakya University Journal of Education Faculty, 6(2), 212-232

Bracey, G., Brooks, M., Marlette, S., \& Locke, S. (2013). Teachers' training: building formal STEM teaching efficacy through informal science teaching experience. In ASQ Advancing the STEM Agenda Conference, Grand Valley State University, Michigan.

Buxton, C. (2001). Exploring science-literacy-in-practice: Implications for scientific literacy from an anthropological perspective. Electronic Journal in Science and Literacy Education, 1(1). Retrieved from http://sweeneyhall.sjsu.edu/ejlts/

Buyruk, B., \& Korkmaz, O. (2016). STEM awareness scale (SAS): validity and reliability study. Journal of Turkish Science Education,11(1), 3-23.

Bybee, R. W. (2013). The case for STEM education: challenges and opportunities. Virginia: NSTA Press, 116 p.

Cevik, M., Danistay, A., \& Yagci, A. (2017). Evaluation of STEM (Science - Technology - Engineering Mathematics) awareness of secondary school teachers with various variables. Sakarya University Journal of Education, 7(3), 584-599.

Cleaves, A. (2005). The formation of science choices in secondary school. International Journal of Science Education, 27(4), 471-486. https://doi.org/10.1080/0950069042000323746

Corlu, M. (2012). A pathway to STEM education: Investigating pre-service mathematics and science teachers at Turkish universities in terms of their understanding of mathematics used in science (Doctoral dissertation). Texas A \& M University.

Corlu, M. A., \& Aydin, E. (2016). Evaluation of learning gains through integrated STEM projects. International Journal of Education in Mathematics, Science and Technology, 4(1), 20-29. https://doi.org/10.18404/ijemst.35021

Corlu, M. S., Capraro, R. M., \& Capraro, M. M. (2014). Introducing STEM education: implications for educating our teachers for the age of innovation. Education and Science, 39(171), 74-85

Derin, G. Yasin, O, Aydin, E., \& Delice, A. (2014). Adaptation of STEM Integration scale to Turkey sampling. Paper presented at the XI. Ulusal Fen Bilimleri ve Matematik Egitimi Kongresi, Adana. Turkiye.

Deveci, İ., \& Cepni, S. (2015). Development of entrepreneurship scale towards student teachers: a validity and reliability study. International Journal of Human Sciences, 12(2), 92-112. https://doi.org/10.14687/ijhs.v12i2.3240

Gencer, A. S. (2015). Scientific and engineering practices in science education: twirly activity. Journal of Inquiry Based Activities, 5(1), 1-19.

Gonzalez, H. B., \& Kuenzi, J. J. (2012). Science, technology, engineering, and mathematics (STEM) education: a primer. Congressional Research Service, Library of Congress.

Guzey, S. S., Harwell, M., \& Moore, T. (2014). Development of an Instrument to assess attitudes toward Science, Technology, Engineering, and Mathematics (STEM). School Science and Mathematics, 114(6), 271-279. https://doi.org/10.1111/ssm.12077

Haciomeroglu, G., \& Bulut, A. S. (2016). Integrative stem teaching intention questionnaire: a validity and relaibility study of the Turkish form. Journal of Theory and Practice im Education, 12(3), 654-669.

Irmis, A., \& Barutcu, E. (2012). The factors seeing themselves as entrepreneurs personalities and establishing new 
business intentions of students: a case study. Ataturk University Journal of Economic And Administrative Sciences, 2, 1-24.

Karakaya, F., \& Avgin, S. S. (2016). Effect of demographic features to middle school students' attitude towards STEM. Journal of Human Sciences, 13(3), 4188-4198. https://doi.org/10.14687/jhs.v13i3.4104

Karakaya, F., Unal. A., Cimen, O., \& Yilmaz, M. (2018). Stem awareness levels of science teachers. Journal of Research in Education and Society /JRES, 5(1), 124-138.

Karasar, N. (2014). Scientific Research Methods, Ankara: Nobel Academic Publishing, 26.

Ministry of National Education [MEB]. (2006). General qualifications of teaching profession. General Directorate of Teacher Education, Ankara.

Ministry of National Education [MEB]. (2016). STEM education report. General Directorate of Innovation and Education Technologies, Ankara.

Nadelson, L. D., Seifert A., Moll, A. J. \& Coat, B. (2012). I-STEM Summer Institute: An integrated approach to teacher professional development in STEM. Journal of STEM Education, 13(2), 69-83.

Naktiyok, A. (2004). Internal entrepreneurship. İstanbul: Beta Publishing.

Ozbilen, A. G. (2018). Teacher opinions and awareness about stem education. Scientific Educational Studies, 2(1), 1-21.

Ozkan, S,. Gundogdu, F., Emsen, S., \& Aksu, H. (2003). Entrepreneurship and its determinants in Turkey: an analysis in Marmara and Eastem Anatolia Region. Ankara University Journal of Faculty of Political Sciences, 58(4), 146-172.

Pan, V. L. \& Akay, C. (2015). ). Examining teacher candidates' entrepreneurship levels in terms of various variables. E-Journal of New World Sciences Academy. Education Sciences, 10(2).

Pinnell, M., Rowley, J., Preiss, S., Franco, S., Blust, R., \& Beach, R. (2013). Bridging the gap between engineering design and PK-12 curriculum development through the use of the STEM education quality framework. Journal of STEM Education, 14(4), 28-35.

Rae, D., \& Carswell, M. (2001). Toward a conceptual understanding of entrepreneurial learning. Journal of Small Business and Enterprise Development, 8(2), 150-158. https://doi.org/10.1108/EUM0000000006816

Riechert, S., \& Post, B. (2010). From skeletons to bridges \& other STEM enrichment exercises for high school biology. The American Biology Teacher, 72(1), 20-22. https://doi.org/10.1525/abt.2010.72.1.6

Roberts, A. (2012). A justification for STEM education. Technology and Engineering Teacher, 71(8), 1-4.

Sahin, A., Ayar, M. C., \& Adiguzel, T. (2014). STEM related after-school program activities and associated outcomes on student learning. Educational Sciences: Theory and Practice, 14(1), 309-322.

Schmidt, K. M., \& Kelter, P. (2017). Science Fairs: A Qualitative Study of Their Impact on Student Science Inquiry Learning and Attitudes toward STEM. Science Educator, 25(2), 126-132.

Teaching Institute for Excellence in STEM. (2010). What is STEM Education? Retrieved from http://www.tiesteach.org/stem-education.aspx.

Yamak, H., Bulut, N., \& Dundar, S. (2014). The impact of STEM activities on 5th grade students' scientific process skills and their attitudes towards science. Gazi University Journal of Gazi Education Faculty, 34(2).

Yenilmez, K., \& Balbag, M. Z. (2016). The stem attitudes of prospective science and middle school mathematics teachers. Journal of Research in Education and Teaching, 5(4), 301-307.

Yildirim, B., \& Selvi, M. (2015). Adaptation of STEM attitude scale to Turkish. Turkish Studies, 10(3), 1107-1120. https://doi.org/10.7827/TurkishStudies.7974

Yildirim, B., \& Altun, Y. (2015). Investigating the effect of STEM education and engineering applications on science laboratory lectures. El-Cezerî Journal of Science and Engineering, 2(2), 28-40.

Yildirim, H. (2008). Entrepreneurial fire and business angels. Degisim Publishing, Istanbul.

Yilmaz, E., \& Sunbul, A., M. (2009). Developing Scale Of University Students Entrepreneurship. Selcuk University Journal of Institute of Social Sciences, (21).

\section{Copyrights}

Copyright for this article is retained by the author(s), with first publication rights granted to the journal.

This is an open-access article distributed under the terms and conditions of the Creative Commons Attribution license which permits unrestricted use, distribution, and reproduction in any medium, provided the original work is properly cited. 